\title{
Countermeasures and paths for optimizing government performance management
}

\author{
Sun Ying \\ Party School of the Central Committee of Liao Ning Provincial Party Committee, Shenyang, P.R. \\ China \\ 12017366@qq.com
}

Keywords: Performance management, assessment indicators, Improvement measures

\begin{abstract}
Performance management is the further development of performance appraisal, and it adds performance counseling to the process of the performance formation of the appraisal object. The marginal effect of government performance management is mainly reflected in two aspects: politics and management. At the political level, it mainly plays the role of democratization of administration, openness of government information and participation of citizens. At the management level, it mainly plays the role of strategic implementation, personnel management and improvement.
\end{abstract}

\section{Introduction}

Performance management is the further development of performance appraisal. Therefore, we should start with institutional arrangements; enhance the consciousness and initiative to speed up the transformation of the mode of economic development. In light of the strategic objectives of economic and social development and the current key work, we must reform the current government performance appraisal system as soon as possible to adapt to the new situation, new tasks and new requirements.

\section{The main problems of government performance appraisal system}

It should be said that the performance appraisal has played a positive role in promoting economic and social development and the government's own construction. However, compared with the strategic objectives of the overall revitalization, the existing government performance appraisal system exists many problems, such as index system is unscientific, management system is not smooth, evaluation methods are backward, performance management innovation motivation is insufficient and so on.

\subsection{Not recognizing the importance of government performance appraisal system from a strategic perspective}

To promote social development, it is necessary to establish correct political performance; To establish and adhere to the correct concept of political performance, we must have a scientific government performance evaluation system. At the same time, deepening the reform of administrative system and building a service-oriented government need to be guided and restrained by a scientific performance appraisal system. However, some governments and their departments only regard the government performance appraisal system as a tool of year-end ranking. Therefore, in the process of promoting the reform of the administrative system, the guiding role of the government performance appraisal system is not prominent, and the function of supervision and restraint is not obvious. 


\subsection{Imperfect system makes the performance management work unable to carry out effectively}

Firstly, the government performance appraisal departments have low specifications, weak organizational and coordination ability, and can't play a leading role in grasping the comprehensive work. Secondly, there is a lack of communication and coordination mechanism between the government performance appraisal system and the department performance appraisal system, as well as between the appraisal subjects, resulting in problems such as inconsistent standards. Thirdly, the lack of effective connection between the government performance appraisal system and the cadre appraisal system not only leads to repeated appraisal, but also reduces the authority of the government performance appraisal system.

\subsection{The performance index system is not scientific}

First of all, indicators do not fully reflect the requirements of development. There are many problems, such as paying more attention to quantity than quality, paying more attention to economy than society, paying more attention to short-term than long-term, paying more attention to input than output, paying more attention to speed than scale. Secondly, the boundaries of indicators are not clear, indicators are set repeatedly, there is a phenomenon of repeated addition, there is also a phenomenon of repeated subtraction. Finally, the proportion of indicators is unbalanced, and the work can't coordinate development.

\subsection{Methods of examination and assessment are backward}

Firstly, the backward manual operation method can't let the leaders get timely, accurate and comprehensive performance information, and the evaluation results are also very easy to be interfered by human factors. Secondly, the lack of effective performance management links such as ordinary assessment and performance counseling, performance appraisal work only stays in a state of simple repetition; Thirdly, due to the lack of verification links, the phenomenon of data fraud is more serious, the accuracy of the assessment work is low, and the recognition of the assessment results is not high. Fourth, the lack of comprehensive performance results and scientific recommendations for improvement feedback link, objectively guide local governments to pursue ranking, rather than improve the work.

\subsection{Public comment is not enough}

Let the public evaluate the government's performance can not only protect the people's right to participate and supervise, but also is a necessary measure to build a service-oriented government that the people are satisfied with. However, in the current government performance evaluation system, the evaluation subject seldom sees the people's participation. First of all, the performance appraisal system introduces social evaluation indicators, but the proportion is low, public evaluation is easy to be alienated. Secondly, the social evaluation can't fully reflect the effect of public services provided by the first-level government or government departments.

\subsection{The safeguard mechanism of government performance appraisal is not in place}

The government performance appraisal work lacks the legal basis, thus lacks the rigid restraint safeguard system, the performance appraisal work often changes along with the leader. The lack of incentive mechanism is mainly manifested in the inadequate use of the evaluation results, the evaluation results are not organic with the performance of cadres and their promotion and exchange, and not organic with the scientific reward and punishment system.

\section{Suggestions for improvement of government performance appraisal system}

To solve the above problems, we should incorporate the government performance appraisal system into the whole government management ecosystem, combine with the actual economic and social development, start with improving the system and mechanism, and speed up the formulation of feasible countermeasures to promote the scientific government performance appraisal system. 


\subsection{Promoting performance evaluation to performance management}

Performance evaluation is a key link of performance management, and performance improvement is the logical starting point and end point of performance management. In recent years, the "Government Work Report" and some important conferences have repeatedly stressed the implementation of administrative accountability system and government performance management system. At the same time, performance management organizations should establish performance counseling system, obtain and feedback performance evaluation information system, improve the work system according to the results of performance evaluation, so as to promote performance evaluation gradually towards performance management.

\subsection{Speed up the pace of legislation and formulate the regulations on government performance management}

In the local laws and regulations of government performance management, the purpose and basic principles, subjects and objects, working mechanism and relevant systems, basic contents and main methods of each link, application of results and legal responsibilities of governments at all levels should be standardized. Through legislation, the government's performance management can be promoted to standardize and legalize, and the authority of the government's performance management can be greatly improved.

\subsection{Reform the performance management system and achieve effective convergence of various performance evaluation systems}

The purpose of reforming the performance management system is to solve the institutional obstacles of low-level and overlapping responsibilities of performance management organizations, so as to achieve effective convergence of organizational performance, personnel performance and project performance. Therefore, we should improve the level of the performance management office, and give the person in charge of the performance office the right to attend or attend the government executive meeting. Establish a joint meeting system to achieve smooth communication and effective coordination among the member units of supervision, legal system, finance, audit, etc. The linkage mechanism between government work department performance evaluation and subordinate government performance evaluation should be established. Then, establishing the linkage mechanism of project evaluation, policy evaluation and organizational performance evaluation.

\subsection{Promoting the scientization of government performance indicators system}

Establishing a scientific performance indicator system is the key to effective performance management. In order to promote the scientization of the government performance index system, firstly, we should design the first-level indicators according to the regional development strategy and the second-level indicators according to the development requirements. We should fully consider the local resource endowment and the characteristics of government functions to determine the performance indicators of the first-level government and the performance indicators of its work departments. We should use logical decomposition to decompose organizational goals into individuals.

\subsection{Innovating performance appraisal methods to improve the credibility of performance appraisal work}

The modern assessment methods and means are the conditions and guarantee for the effective operation of the performance evaluation system. Therefore, it is necessary to promote the information, networking and openness of performance appraisal system, effectively solve the problem of asymmetric performance information, create efficient management tools for leaders, and build a low-cost, high-quality, convenient and fast platform for government performance management for appraisal subjects and appraisal objects.; The government performance appraisal 
cycle should be designed scientifically, which combines peacetime, annual and term appraisal to realize the whole process management of government performance.

\subsection{Scientifically determining the main body of government performance appraisal}

Following the direction of combining internal evaluation with external evaluation, different performance evaluation subjects are determined according to different types of indicators. At the same time, we should strengthen the external evaluation, let the public, service objects, power organs, the third sector and experts participate in the whole process of evaluation, and realize the three-dimensional evaluation of government work.

\subsection{Establishing and improving the guarantee mechanism of government performance management}

In order to make the local government performance evaluation less interfered by human factors, besides promulgating local laws and regulations, it is necessary to establish the guarantee mechanism of personnel quality, management system and result application. Establish a regular training system to improve the fair and responsible consciousness and professional ability of performance appraisers, performance managers and performance supervisors. Establish relevant systems to ensure the authenticity and accuracy of performance information and the objective and fair results of performance appraisal. Fully utilizing the results of performance appraisal, the results of performance appraisal will be combined with the use of cadres, incentives for rewards and punishments and improvement work, so as to ensure the effective implementation of government performance management.

\subsection{Organize public satisfaction survey}

It is suggested that the performance management department of the provincial government should take the lead and be jointly organized and implemented by many departments, mainly responsible for the activities of index refinement, questionnaire design, organizational investigation, data analysis, countermeasure research, report formation and so on. The subjects of public satisfaction and well-being survey should include both urban and rural residents, enterprises and individual businesses. Investigation reports should be made public in time, and rigid restrictions should be imposed on organizers, investigators and respondents so as to ensure the fair and just conduct of the activity. Public satisfaction and well-being are included in the government performance evaluation index system, and given a higher weight coefficient.

\section{Conclusion}

To carry out government performance management, we should design an index system around the central work of the government and the deployment of major decision-making. Therefore, government performance management plays a role in strategic implementation. The results of performance appraisal are used in personnel training, communication, promotion, reward and punishment activities, so performance management provides the basis for personnel management. The fundamental purpose of performance management is to improve the work, so performance management plays a role in improving.

\section{References}

[1] Kevin Baird, Herbert Schoch,Qi (James) Chen, Performance management system effectiveness in Australian local government, Pacific Accounting Review, pp. 161-185,2012.

[2] Victor Y. Haines, Sylvie St-Onge, Performance management effectiveness: practices or context? The International Journal of Human Resource Management, pp. 1158-1175, 2012. 